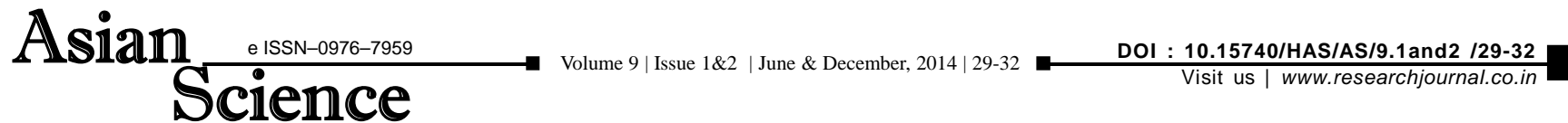

RESEARCH PAPER

\section{Socio-economic profile of women and their knowledge about development programmes}

\author{
SEEMAPRAKALPA* AND POOJA MISHRA \\ Department of Home Science Extension, Kr. R.C.M.P.G. College (BRAU), MAINPURI (U.P.) INDIA
}

\begin{abstract}
It has been commonly assessed by everyone that women are the key factor in the process of change and development. So Government plan and execute several programme for their development because they are the half of the entire population. The successful development requires the fuller participation of its natural and human resources. Any real attempt regarding socio-economic development must be viewed as a movement involving all segments of society. For assessing socio-economic profile of women functionaries, scale of Trivedi (1963) was used with slight modification. Interview schedule was used to collect primary data. Therefore, the aim of present study was to identify socio-economic profile of women and their knowledge about Government programmes. The findings of the present study show that majority of the respondents were in the age-group of 30-40 yrs., illiterate, belonged to schedule caste, from nuclear family having 5-8 members. They were aware about the programmes namely; Vridhavasthana Pension Yojna and Vidhava Pension Yojna. They were participating in Vidhava Pension Yojna and Indira Awas Yojna. Therefore, efforts should be made to aware firstly and secondly to facilitate them before executing the beneficial programmes.
\end{abstract}

Key Words : Women, Programmes, Knowledge, Awareness

View point paper : Seemaprakalpa and Mishra, Pooja (2014). Socio-economic profile of women and their knowledge about development programmes. Asian Sci., 9 (1\&2): 29-32.

\footnotetext{
* Author for correspondence

Seemaprakalpa, Department of Home Science Extension Education, Institute of Home Science, Dr. B.R. Ambedkar University, AGRA(U.P.) INDIA

(Email: prakalpass@gmail.com)
} 